\title{
Efficiency from a pneumatic system to a mechanical traction system
}

\section{Eficiencia de un sistema neumático a un sistema de tracción mecánica}

PERALTA-MEZA, Angel†*, PENDONES-FERNÁNDEZ, José Angel and DURÁN-NÚÑEZ, Félix Arnoldo

Instituto Tecnológico Superior de Nuevo Casas Grandes

ID $1^{\text {st }}$ Author: Angel, Peralta-Meza / ORC ID: 0000-0003-0295-3545

ID $1^{\text {st }}$ Coauthor: José Angel, Pendones-Fernández / ORC ID: 0000-0001-6993-1995, CVU CONACYT ID: 660600

ID $2^{\text {nd }}$ Coauthor: Félix Arnoldo, Durán Núñez / ORC ID: 0000-0001-998-8781, CVU CONACYT ID: 1010275

DOI: $10.35429 /$ JOIE.2021.16.5.25.29

Received April 16, 2021; Accepted June 30, 2021

\begin{abstract}
Pneumatic traction systems have already been used since Denise Papín, who apparently already had the idea of using compressed air in cars. Currently in Uruguay and India with Armando Miguel Regusci Campomar and the French inventor Guy Negre respectively, they make use of this energy and mention high efficiency in their compressed air motors. In this vein and in order to continue research with this energy, explore non-polluting alternative energies and their efficiency, a PneumaticMechanical traction system is proposed in this research, in a mobile of our own manufacture. The system works under two principles of elementary physics; Pascal's pneumatic energy and Tesla's alternating pneumatic energy that is, alternating pneumatic energy, their efficiency is tested with the energy of the compressed air tank and the displacement energy of the mobile
\end{abstract}

Compressed air, Pascal, pneumatic

\section{Resumen}

Los sistemas de tracción neumática ya han sido usados desde Denise Papín, quien al parecer ya tuvo la idea de usar el aire comprimido en los autos. Actualmente en Uruguay y la india con Armando Miguel Regusci Campomar y el inventor francés Guy Negre respectivamente, hacen uso de esta energía y mencionan una alta eficiencia en sus motores de aire comprimido. En este tenor y en pro de continuar la investigación con esta energía, explorar energías alternativas no contaminantes y su eficiencia, se propone en esta investigación un sistema Neumático-Mecánico de tracción, en un chasis de fabricación propia. El sistema funciona bajo dos principios de física elemental; energía neumática de pascal y el principio de intermitencia de tesla, es decir energía neumática alterna, se prueba su eficiencia con la energía del depósito de aire comprimido y la energía de desplazamiento del móvil.

Aire comprimido, Pascal, neumática

Citation: PERALTA-MEZA, Angel, PENDONES-FERNÁNDEZ, José Angel and DURÁN-NúÑEZ, Félix Arnoldo. Efficiency from a pneumatic system to a mechanical traction system. Journal of Innovative Engineering. 2021. 5-16: 25-29

*Correspondence to Author (e-mail: aperalta@itsncg.edu.mx)

$\dagger$ Researcher contributing as first Author. 


\section{Introduction}

At the present time, most of the energy that the planet uses has its main source in non-renewable resources, it is necessary to preserve raw materials (gas and oil) that allow the generation of a large amount of diffused inputs and that, by their nature, they have the ability to impact a large number of industries, to achieve this it is necessary to identify alternative sources for power generation (Armenta Fraire, ene. 2009). Changing climatic conditions, environmental regulations against emissions and the possibility of shortages and high prices of fossil fuels, make it increasingly favorable to adopt generation technologies from non-conventional renewable sources (Isaza, 2015).

The objective and interest of this research is to take up and verify the study of a technology that others have already assimilated in previous decades, in the struggle to continue improving the use of alternative energy (compressed air), basically it is to confirm its efficiency and continue with the study about the use of compressed air, in different applications such as; motors, pumps, generators, cars, etc. to get by without polluting expensive energies with clean and efficient systems.

Some researchers are mentioned as; Denise Papín who had the idea of using compressed air in 1687 which consisted of a pneumatic transmission (Kassel, 1707). Andraud and Tessie de Motay's first compressed air vehicle in 1838 (Blázquez Morales, 2021). In 1872 the Mekarski air engine which was used in numerous locomotives (Scott, 2016) In January 1975 Sorgato, in Italy, proposed the compressed air motor as a viable source and alternative to the electric car for industrial and urban use.

The first experimental model had nine bottles of air charged to 2840 PSI by an external compressor. The maximum speed of this silent and non-polluting vehicle was $50 \mathrm{~km} / \mathrm{h}$. with an autonomy of approximately two hours (Scott, 2016) In 1979, Terry Miller determined that compressed air was the perfect energy storage medium. (Robertson, 2021). In 1980 Carl Leissler developed an engine that could run on air (Scott, 2016) In May 1987 an article was published about the inventor Ricardo PérezPomar from Miami (Scott, 2016)
In 2008 there were already about a dozen people among them; in Uruguay and India with Armando Miguel Regusci Campomar (Regusci, 2018) and French inventor Guy Negre (Costas, 2012) respectively as companies that are developing compressed air motors applied to transport, in addition to numerous companies that manufacture and commercialize pneumatic motors for application to industry. Therefore, in order to dispense with polluting energies and promote alternative energies, the objective of this work is to verify the energy efficiency in the traction system of a proposed alternative Pneumatic-Mechanical traction system.

Therefore, a Pneumatic-Mechanical traction system is shown for such purposes, which consists of two pistons attached to a belt by means of a pulley, which serves for the return of each piston without the use of a spring, and a valve that actuates one piston at a time, coupled to a chassis of our own manufacture. The system works under two principles of elementary physics; Pascal's pneumatic energy provided by a pressure tank and the diameter of the actuator piston, and Tesla's intermittency principle, that is, alternating pneumatic energy, which consists of driving the shaft with a unidirectional pinion. To find out its efficiency, the energy of the compressed air tank and the moving energy of the mobile are calculated and thus the efficiency of the pneumatic-mechanical traction system is verified.

\section{Materials and methods}

\section{Compressed air storage system}

The pressure energy of the tank is determined by the following formula:

$$
E_{\text {Pressure }}=P_{\text {deposit }} v_{\text {deposit }}
$$

Where:

$\mathrm{E}=$ energy; joules

$\mathrm{P}=$ pressure; $\mathrm{N} / \mathrm{m}^{2}(\mathrm{~Pa})$

$\mathrm{V}=$ volume $; \mathrm{m}^{3}$

The prototype consists of two cylinders, each with the following dimensions: $0.16 \mathrm{~m}$ in diameter by $0.46 \mathrm{~m}$ in length, therefore:

$$
\begin{aligned}
& V=\frac{\pi D^{2}}{4} \times h \\
& V=\frac{\pi(0.16 m)^{2}}{4} \times 0.46 m \times 2 d
\end{aligned}
$$


$V=0.018497 \mathrm{~m}^{3}$

Where:

$\mathrm{D}=$ cylinder diameter

$\mathrm{h}=$ cylinder height

The pistons receive a pressure of 655002 Pascals provided by the compressed air, therefore, the pressure energy is:

$$
E_{\text {pressure }}=(655002 \mathrm{~Pa})\left(0.018497 \mathrm{~m}^{3}\right)=
$$

\subsection{Joules}

\section{Chassis}

The structure of the mobile chassis is designed to be rigid in order to withstand the bending and torsional stresses Figure 1, which must be rigid to withstand the bending and torsional stresses, a simple analysis is made with Solid Works software, based on a previous design of the first chassis of the Ford T.

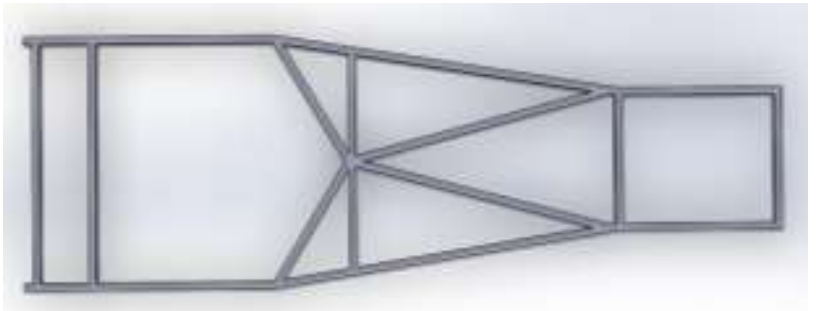

Figure 1 For T model chassis

Source: own design in Solid Works

\section{Front suspension}

Then, the dimensions of the front suspension are determined, figure 2: hub, forks and ball joints, with the help of the Vsusp software (Open Source, 2020) It is possible to find the center of mass and the center of inertia for stable mobility under work conditions.

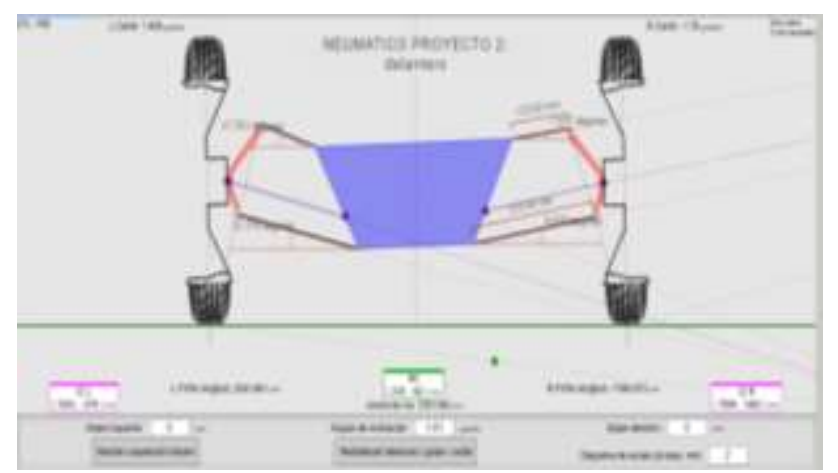

Figure 2 Front suspension model

Source: lead (Open Source, 2020)

\section{Pneumatic control system}

Mechanical sensors (A1 and A2), in addition to controlling the reciprocating movement, have the function of shortening the stroke distance of the power pistons, with manual control Figure 3. The pressurized air supply to the cylinders is controlled with a flow regulating valve. The supply pressure of the pneumatic system is controlled by the pressure regulating high power holding unit.

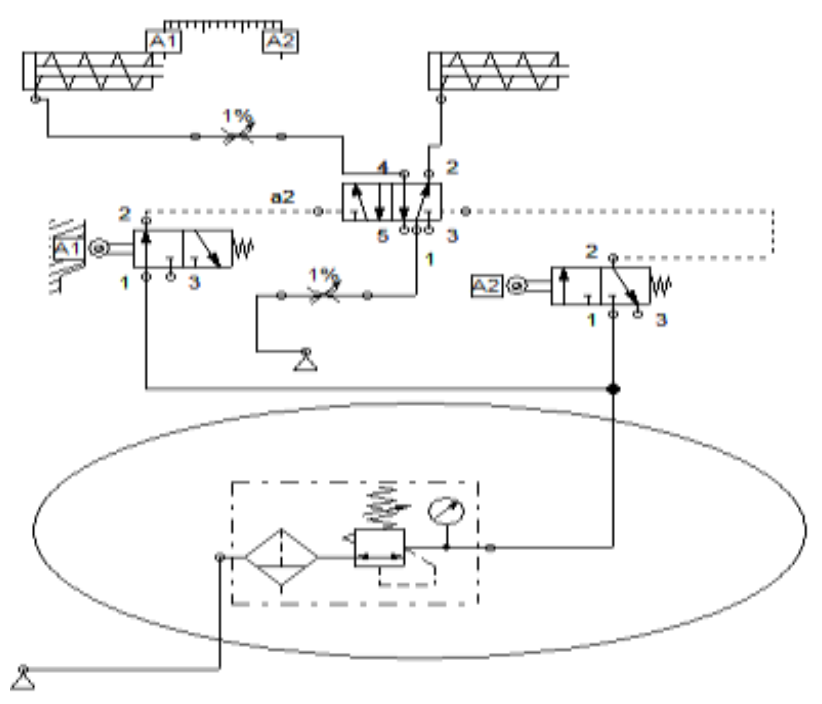

Figure 3 Pneumatic Circuit Source: Own design in Fluid Sim

\section{Traction system}

The mechanical system uses a $60 \mathrm{~mm}$ pinion with 26-inch wheels, this transmission is unidirectional only as shown in Figure 4, and it is supported by a pair of springs, the rear suspension system has the ability to adapt to the movement with a pair of universal joints.

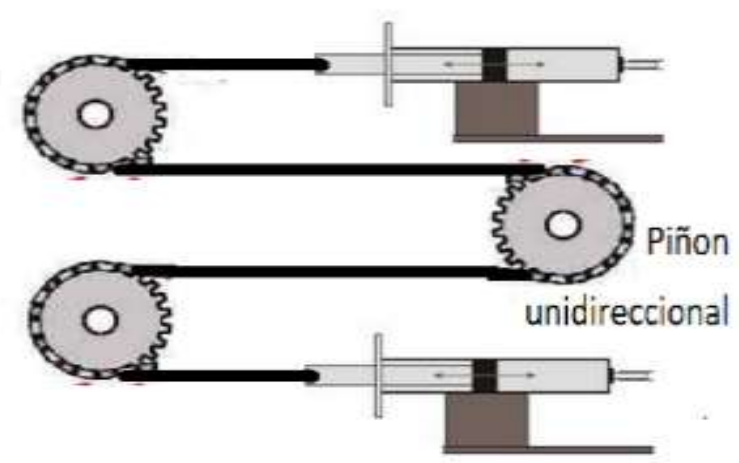

Figure 4 Mechanical traction system Source: own elaboration in Paint 


\section{Test running}

The system starts causing the sequence of alternating movements of the two cylinders so that the traction wheel rotates and the movement of the mobile starts, which has a net weight of $280 \mathrm{Kg}$. The movement of the mobile was 62 meters in a time of 32 seconds, therefore the average speed is $1.9375 \mathrm{~m} / \mathrm{s}$. The output energy is calculated by the kinetic energy equation:

$$
E_{K}=\frac{m v^{2}}{2}
$$

\section{Where:}

$E_{k}=$ kinetic energy in joules $(J)$

$\mathrm{m}=$ mass in kilograms $(\mathrm{Kg})$

$\mathrm{v}=$ speed in meters per second $(\mathrm{m} / \mathrm{s})$

$$
\begin{aligned}
& E_{K}=\frac{(280 \mathrm{Kg})\left(\frac{1.9375 \mathrm{~m}}{\mathrm{~s}}\right)^{2}}{2} \\
& E_{k}=525.546875 \mathrm{~J}
\end{aligned}
$$

\section{Results}

Based on the data collected on the input and output energy, we can deduce the efficiency of the system.

$$
\begin{aligned}
& \eta=\frac{E_{\text {output }}}{E_{\text {input }}}=\frac{525.5468 \mathrm{~J}}{12115.57 \mathrm{~J}} \times 100 \%= \\
& 4.337 \%
\end{aligned}
$$

\section{Gratitude}

Thanks to the Higher Technological Institute of Nuevo Casas Grandes, the National Technological Institute of Mexico and the Municipal Presidency of Nuevo Casas Grandes.

\section{Conclusions}

The system has an efficiency of $4.33 \%$, this shows that it is very inefficient, considering that this energy alternative is currently under research and that other inventors of compressed air systems indicate that is very efficient compared with the efficiency in costs per liter of gasoline, this subject needs further research. In addition to designing a new traction mechanism, it was relevant to check the efficiency of compressed air actuated systems, including the Regusci model, which, unlike its model, the designed prototype does not use a stem return spring.
Regarding the conversion mechanism, it is observed that autonomy can be improved by using a larger capacity tank and also with a compressor that supplies more pressure, taking into account that there are models with tanks that support up to 3000psi.

For future research on this topic, it is recommended to model a hybrid system of gasoline and pressurized air, and meet four Scott Tinker criteria to produce energy: environmental compatibility, affordability, availability and reliability of the work element.

\section{References}

Armenta Fraire, L. (ene. 2009). Energia y politica publica. uplemento especial: Primer Seminario Internacional en Teoría Económica Contemporánea (pp. 161-164). Zapopan : EconoQuantum vol.6 no.1 .

Blázquez Morales, L. F. (2021). Galerias tematicas. Retrieved from Museo Virtual: $\mathrm{http} / / /$ historico.oepm.es/museovirtual/galerias_t ematicas.php?tipo $=$ CURIOSAS $\&$ xml $=$ Privilegi о\%20n\%C2\%BA\%20328.xml

Blázquez Morales, Luis Fernando;. (Copyright 2016-2021). Museo Virtual. Retrieved from Galerias tematicas: http://historico.oepm.es/museovirtual/galerias_t ematicas.php?tipo=CURIOSAS $\&$ xml=Privilegi o\%20n\%C2\%BA\%20328.xml

Carta González, J. A., Calero Pérez, R., Colmenar Santos, A., \& Castro Gil, M. A. (2009). Centrales de energías renobables. Madrid: PEARSON EDUCATIÓN.

Costas, J. (2012, 04 13). Motor Pasion. Retrieved from https://www.motorpasion.com/coches-hibridosalternativos/tata-mini-cat-este-si-que-se-muevesolo-con-aire

De la orden Fresno, L., \& Mochón Castro, L. (2013). Diseño de un Prototipo comercial impulsado por aire comprimido. Madrid: Universidad Pontificia ICAI ICADE.

Isaza Cuervo, F. (julio-diciembre de 2015). Valoración de fuentes renovables no convencionales de generación de electricidad: un enfoque desde las opciones reales. Cuad. admon.ser.organ, 45-64. 
J Busso, A., Reu, M., Müller, J., \& Sogari, N. (n.d.). Almacenamiento subterraneo de energia termica: resultados de un ensayo. Facultad de Ciencias Exactas, 4.

Kassel, J. E. (1707). Denis Papin, Nouvelle manière pour lever l'eau par la force du feu. France: Bibliothèque nationale de France.

Open Source. (2020). Vsusp 0.7. Windows: England.

Regusci, A. M. (2018, 07 23). REGUSCI AIR. Retrieved from http://www.regusciair.com/

Robertson, S. (2021). The Truth About Air Cars. Retrieved from Internet Archive: https://archive.org/search.php?query=\%22truth +about+air+cars\%22+\%22pneumatic+options $\% 22 \&$ sort $=$ creatorSorter

Scott, R. (2016, 05 7). Biblioteca de investigación de opciones neumáticas. Retrieved from Internet Archive: http://www.aircaraccess.com/download.htm

Scott, R. (2016, 05 07). Internet Archive. Retrieved from https://archive.org/details/taac2 Theodore Simons, E. M. (1914). Compressed Air. 239 Wets 39Th Street, New York: McGrawHill Book Company, Inc. 